\title{
Updates to the fauna of dragonflies (Odonata) of the Altaiskii Krai with new records of species for Siberia
}

\section{К фауне стрекоз (Odonata) Алтайского края с указанием новых видов аля Сибири}

\section{S.N. Borisov \\ С.Н. Борисов}

Institute of Systematics and Ecology of Animals, Russian Academy of Sciences, Siberian Branch, Frunze Str. 11, Novosibirsk 630091 Russia. E-mail: borisov-s-n@yandex.ru.

Институт систематики и экологии животных СО РАН, ул. Фрунзе 11, Новосибирск 630091 Россия.

Key words: Odonata, Sympecma fusca, Anax imperator, Orthetrum albistylum, Orthetrum brunneum, Altaiskii Krai, Siberia.

Ключевые слова: Odonata, Sympecma fusca, Anax imperator, Orthetrum albistylum, Orthetrum brunneum, Алтайский Край, Сибирь.

Abstract. 35 dragonfly species were recorded during an expedition to the Altaiskii Krai, three of which, Sympecma fusca (Vander Linden, 1820), Anax imperator Leach, 1815 and Orthetrum brunneum (Fonscolombe, 1837), are recorded for Siberia for the first time. New data on the occurrence of the rare and little-known species Ischnura pumilio Charpentier, 1825, Anax parthenope (Selys, 1839) and Orthetrum albistylum (Selys, 1839), are provided. A new record of the migrant species Sympetrum fonscolombii (Selys, 1840) in Siberia is also presented.

Pезюме. Во время экспедиции в Алтайский край отмечено 35 видов стрекоз. Для Сибири впервые приводятся три новых вида - Sympecma fusca (Vander Linden, 1820), Anax imperator Leach, 1815 и Orthetrum brunneum (Fonscolombe, 1837), также данные о встречах редких и малоизвестных видов Ischnura pumilio Charpentier, 1825, Anax parthenope (Selys, 1839), Orthetrum albistylum (Selys, 1839). Сообщается также о новой находке в Сибири видамигранта Sympetrum fonscolombii (Selys, 1840).

\section{Introduction}

The fauna of dragonflies in the Altaiskii Krai, as well as in most part of Siberia as a whole, has been studied quite well by now [Belyshev, 1958, 1968, 1973; Kosterin 1987; Haritonov et al., 2007; Malikova, Kosterin 2019]. Nevertheless, an expedition to the Altai steppes made it possible to replenish information about dragonflies in this region and find there a number of little-known and new species not only for the Altaiskii Krai, but also for Siberia in general.

The expedition was completed in the period from June 28 to July 7, 2020. Research was carried out in the Rubtsovsky and Loktevsky Districts in the South-West and in the Biysk District in the east of the Altaiskii Krai. The work also includes A. Noskova's data on the finding of the migrant species Sympetrum fonscolombii (Selys, 1840) in the city of Biysk.

A total of 35 species of dragonflies were recorded. The places of their collection are shown on the map.
Locality designations correspond to those in the locations list (Fig. 1).

\section{List of localities}

Loc. $1.2 \mathrm{~km}$ south-west of the village of Zakharovo, the Aley River and the pond, 51 $38^{\prime} 16^{\prime \prime} \mathrm{N}, 81^{\circ} 19^{\prime} 08^{\prime \prime} \mathrm{E}$, 205 m a.s.1., 28-29.VI.2020.

Loc. 1a. Ibid, 4.VII.2020.

Loc. $2.3 \mathrm{~km}$ west of the city of Rubtsovsk, a field with shrubby vegetation, 51 $31^{\circ} 58^{\prime \prime} \mathrm{N}, 81^{\circ} 09^{\prime} 37^{\prime \prime} \mathrm{E}, 215$ ma.s.1.29.VI.2020.

Loc. 3. The main channel, $10 \mathrm{~km}$ west of the village of Veseloyarsk, 51०17'35" N, 8057'47" E, $223 \mathrm{~m}$ a.s.1.,4.VII.2020.

Loc. 4. Aley River (near the bridge), $6 \mathrm{~km}$ south of the village of Lokot', 51 $08^{\prime} 38^{\prime \prime}$ N, 81 ${ }^{\circ} 14^{\prime} 23^{\prime \prime}$ E, $240 \mathrm{~m}$ a.s.1., 29.VI.2020.

Loc. 5. Reservoir $(0.6 \mathrm{~km} \times 0.3 \mathrm{~km})$ on the Pilnichikha River and a stream with seeping ground water, $8 \mathrm{~km}$ north of the village of Pokrovka, 51 ${ }^{\circ} 15^{\prime} 23^{\prime \prime} \mathrm{N}, 81^{\circ} 26^{\prime} 42^{\prime \prime}$ E, 285 m a.s.1., 30.VI.2020.

Loc. 6. Reservoir (1.2 km x $0.8 \mathrm{~km})$ on the Eldarka River and semi-flowing reservoirs with seeping ground water, $2 \mathrm{~km}$ east of the village of Bugry, $51^{\circ} 16^{\prime} 59^{\prime \prime} \mathrm{N}$, 81²9'19" E, 290 m a.s.1.,3.VII.2020.

Loc. 7. Middle course of the Ust'yanka River, $4 \mathrm{~km}$ north of the village of Pokrovka, 51 ${ }^{\circ} 13^{\prime} 27^{\prime \prime} \mathrm{N}, 81^{\circ} 28^{\prime} 23^{\prime \prime} \mathrm{E}$, 264 m a.s.1.,29.VI.2020.

Loc. 8. The Aley River and the oxbow river, $2 \mathrm{~km}$ southeast of the village of Pokrovka, $51^{\circ} 09^{\prime} 53^{\prime \prime} \mathrm{N}$, 81²8'23" E, 257 m a.s.l., 1.VII.2020.

Loc. 9. The lower reaches of the Sukhaya River, $6 \mathrm{~km}$ east of the village of Pokrovka, 51 ${ }^{\circ} 10^{\prime} 25^{\prime \prime} \mathrm{N}, 81^{\circ} 32^{\prime} 07^{\prime \prime} \mathrm{E}$, 275 ma.s.l., 2.VII.2020.

Loc. 10. Biysk, Lake Kovalevskoe (within the city), $52^{\circ} 32^{\prime} 10^{\prime \prime} \mathrm{N}, 85^{\circ} 09^{\prime} 43^{\prime \prime}$ E, 180 m a.s.l., 12.VI.2019.

Loc. 11. The Nenya River and its oxbow. Neninka village, 52³9'59" N, 86 ${ }^{\circ} 12^{\prime} 06^{\prime \prime}$ E, 215 ma.s.1., 6-7.VII.2020. 


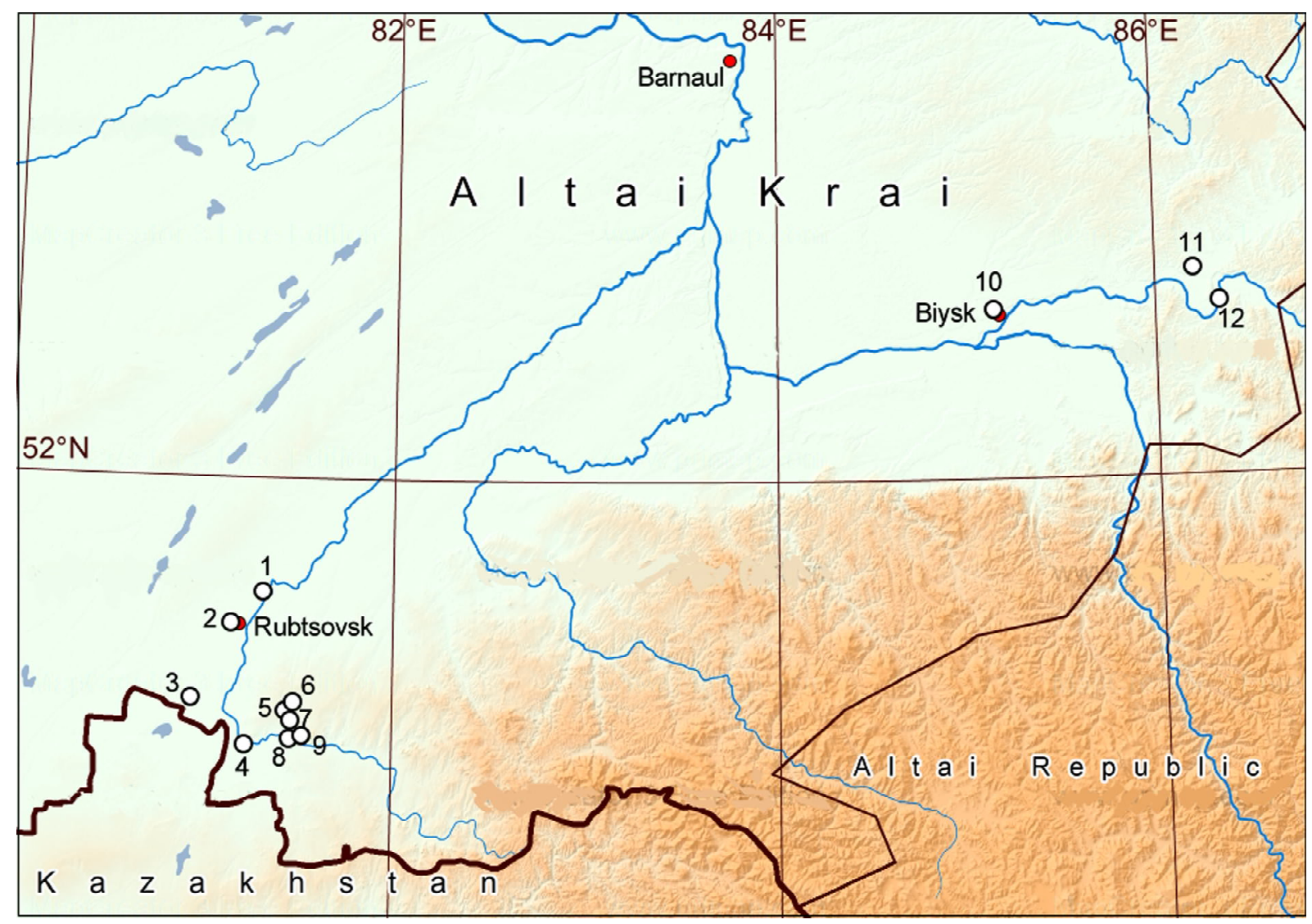

Fig. 1. Map of the Altaiskii Krai with designations of places of dragonfly collected. The locality numbers correspond to those in the locality list.

Рис. 1. Карта Алтайского края с обозначениями мест сбора стрекоз. Номера Аокалитетов соответствуют таковым в списке местонахождений.

Loc. 12. Biya River and oxbow rivers, $1 \mathrm{~km}$ north of the village of Novaya Anzhinka, 52³3'37" N, 86²0'03" E, 209 ma.s.1., 6.VII.2020.

\section{List of species and specimens}

Lestes barbarus (Fabricius, 1798)

Material. Loc:: 6 (19), $8\left(40^{7} 0^{7}\right), 11\left(10^{7}\right)$.

Lestes dryas Kirby, 1890

Material. Loc.: $8\left(10^{7}, 1\right.$ 19).

Lestes macrostigma (Eversmann, 1836)

Material. Loc: 3 ( $20^{7} \odot^{7}, 1$ 1 $), 5$ ( $40^{7} \sigma^{7}, 2$, + + ).

Lestes sponsa (Hansemann, 1823)

Material. Loc: 1 (1ㅇ), 1a $\left(30^{7} \sigma^{7}\right), 2\left(10^{7}\right), 5\left(50^{7} 0^{7}, 1+\right.$ ) $7\left(10^{\top}\right), 11\left(20^{7} \sigma^{7}, 2\right.$ of $)$.

Lestes virens vestalis Rambur, 1842

Material. Loc: 1a (1우), 2 (1우), 5 (10 $\left.0^{7}\right), 11$ (1우).

Notes. For taxonomic status of the eastern representatives of $L$. virens see Schröter et al. [2015].

Sympecma fusca (Vander Linden, 1820)

Material. Loc: $5\left(10^{7}\right), 11\left(10^{7}\right)$.

\section{Sympecma paedisca (Brauer, 1877)}

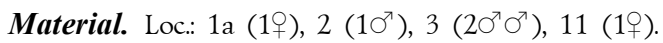

Calopteryx splendens splendens (Harris, 1782)

Material. Loc: $1 \mathrm{a}\left(10^{\mathrm{T}}\right), 3\left(10^{\mathrm{T}}\right), 4\left(30^{\mathrm{T}} \mathrm{O}^{\mathrm{T}}\right), 5\left(10^{\mathrm{T}}\right)$,

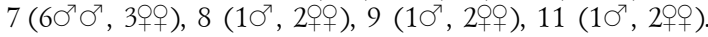

Notes. For the subspecific status of C. s. splendens see Malikova, Kosterin [2019].

Platycnemis pennipes (Pallas, 1771)

Material. Loc: $1 \mathrm{a}\left(1 \sigma^{7}\right), 4\left(2 \sigma^{7} \sigma^{7}\right), 5\left(3 \sigma^{7} \sigma^{7}\right), 6\left(2 \sigma^{7} \sigma^{7}\right)$,

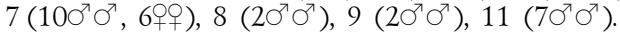

Coenagrion hastulatum (Charpentier, 1825)

Material. Loc.: $11\left(60^{7} \sigma^{7}\right), 12\left(20^{7} \sigma^{7}\right)$.

\section{Coenagrion puella (Linnaeus, 1758)}

Material. Loc: $5\left(10 \sigma^{7} \sigma^{7}\right), 11\left(7 \sigma^{7} \sigma^{7}, 2 \sigma^{7} \sigma^{7}\right), 12\left(2 \sigma^{7} \sigma^{7}\right)$.

Coenagrion pulchellum sibiricum Belyshev, 1964

Material. Loc: $5\left(3 \sigma^{7} \sigma^{7}\right), 11\left(2 \sigma^{7} \sigma^{7}\right)$.

Notes. For the subspecific status of C. p. sibiricum in Siberia see Malikova, Kosterin [2019].

Enallagma cyathigerum risi Schmidt, 1961

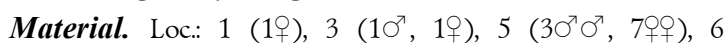

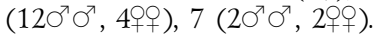


Notes. For the subspecific status of E. c. risi see Kosterin [2004] and Kosterin, Zaika [2010].

Erythromma najas najas (Hansemann, 1823)

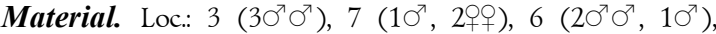
$8\left(10^{7}, 1+\right.$ 운 $), 11\left(50^{7} 0^{7}, 1\right.$ 우 $)$.

Ischnura elegans (Vander Linden, 1820)

Material. Loc: $3\left(40^{7} \sigma^{7}, 1\right.$ 우 $), 5\left(5 \sigma^{7} \sigma^{7}, 19\right), 6\left(10^{7}\right)$,

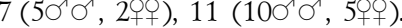

Notes. The current consensus is absence of clear subspecies in I. elegans [Schröter et al., 2015; Kosterin, Ahmadi, 2018; Schneider et al., 2018; Malikova, Kosterin, 2019].

Ischnura pumilio (Charpentier, 1825)

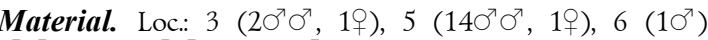
$7\left(2 \sigma^{7} \sigma^{7}\right), 11\left(20^{7} \sigma^{7}\right), 12\left(10^{3}\right)$

Aeshna affinis Vander Linden, 1820

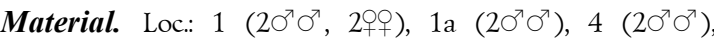
$6\left(10^{7}\right), 7(19), 8\left(10^{7}\right)$.

\section{Aeshna crenata Hagen, 1856}

Material. Loc: $11\left(30^{7} 0^{7}\right)$.

Aeshna grandis (Linnaeus, 1758)

Material. Loc.: 1 (1우), 11 (2우우.

Anax imperator Leach, 1915

Material. Loc.: 5 (20 $0^{7} 0^{7}$ visual), $6\left(10^{7}, 19\right)$

Anax parthenope (Selys, 1839)

Material. Loc: 5 (10 , visually more than $10 \sigma^{7} \sigma^{7}$ patrolling along the coast), $6\left(2 \sigma^{7} \sigma^{7}\right), 7$ (visually pair during egg-laying)

Notes. At present, the species is considered to be monotypic. The closely related $A$. julius Brauer, 1865 replaces $A$. parthenope in the Eastern Palearctic [Kalkman, Proess, 2015a].

Gomphus vulgatissimus (Linnaeus, 1758)

Material. Loc: 11 ( $20^{7} 0^{7}, 2$ 우)

Ophiogomphus cecilia (Geoffroy in Fourcroy, 1785)

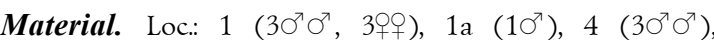
$8\left(20^{2} \sigma^{2}, 2+9\right)$.

Shaogomphus postocularis epophthalmus (Selys, 1872)

Material. Loc: $12\left(10^{7}\right)$.

Stylurus flavipes (Charpentier, 1825)

Material. Loc.: 1 (2우)

Macromia amphigena fraenata Martin, 1906

Material. Loc: 11 (10', visually more than 10 males).

Somatochlora metallica (Vander Linden, 1825)

Material. Loc: $11\left(20^{7} 0^{7}\right)$.

Libellula quadrimaculata Linnaeus, 1758

Material. Loc: $5\left(10^{7}\right), 8(1+), 9\left(10^{7}\right), 10\left(10^{7}\right)$.

Orthetrum albistylum (Selys, 1848)

Material. Loc: 3 (10', visually more than 10 males), 5 $\left(20^{7} 0^{7}, 19\right.$, visually more than 10 males), 6 (10 , visually more than 10 males), 7 (10 $)$
Notes. The eastern subspecies $O$. a. speciosum (Uhler, 1858) was shown to have no reliable diagnostic differences and cannot be supported [Seehausen, Fiebig 2016; Malikova, Kosterin, 2019]. See also Borisov [2016], Borisov, Borisov [2017].

Orthetrum brunneum (Fonscolombe, 1837)

Material. Loc.: 3 (3 $0^{7} 0^{7}$ visual), 5 (10 $\left.0^{7}, 290\right), 6\left(10^{7}\right)$, $7\left(40^{\top} \sigma^{\top}, 1+\right.$ 우 $)$.

Orthetrum cancellatum (Linnaeus, 1758)

Material. Loc: $5\left(10^{7}\right), 6\left(20^{7} 0^{7}, 1+\right.$ 웅.

Sympetrum flaveolum (Linnaeus, 1758)

Material. Loc:: 1 (1우), 2 (1우), 4 (1우), 8 (10 $\left.0^{\top}\right), 9$ (10 $10^{7}$ 우), 11 (3우).

Sympetrum fonscolombii (Selys, 1840)

Material. Loc: 10 (photo by male, A. Noskova).

Sympetrum sanguineum (Müller, 1764)

Material. Loc: 1 (1우), 7 (1우), 8 (1우), 9 (10 $), 11$ (10 , 3우), $12\left(10^{7}\right)$.

Sympetrum vulgatum vulgatum (Linnaeus, 1758)

Material. Loc: 1 (10 ), 1a (1우), 2 (1ㅇ), 4 (1우), 5 (1우), 8 (1우), 9 (1우)

\section{New for Siberia and little-known species}

Sympecma fusca. One male was found in the southwest (loc. 5) and one male in the east (loc. 11) of the Altaiskii Krai. Both individuals were of the last year's brood, which overwintered in adults.

A West-Palaearctic species, previously known in the eastern part of the range only from Middle Asia and Kazakhstan [Borisov, Haritonov, 2007; Kalkman, Willigalla, 2015]. For Siberia, these are the first reliable findings of the species and the most northern and eastern ones in the Asian part of the range. The closest location lies in the north-east of Kazakhstan (Borly Lake, 51 ${ }^{\circ} 49^{\prime} 27^{\prime \prime}$ N, 7756'46" E) [Borisov, Kosterin, 2014].

Ischnura pumilio. Dragonflies of this species are found in 6 localities. In the southwestern part of the Altaiskii Krai, I. pumilio was common in small reservoirs (loc. 5, 6) and on the warm Ust'yanka River with a predominantly soil type of feeding (loc. 7).

A West-Palaearctic species penetrating eastward to Mongolia and Inner Mongolia in northeastern China [Dumont, 2003; Boudot, Šalamun, 2015]. In the south of Western Siberia, it is distributed locally. It was previously known there from the village of Tochilino (the correct name is Tochilnoye) in the Altaiskii Krai [Belyshev, 1958], Lake Manzherok in the Altai Republic [Kosterin, 1987], in the Khemchik depression and Central Tuvinian depression in Tuva [Kosterin, Zaika, 2010] and in Novosibirsk (Akademgorodok) [Kosterin, 2013]. In Eastern Siberia, the species is known only from an old report from Irkutsk [Selys-Longchamps, McLachlan, 1872].

Anax imperator. The species is recorded for the first time in Siberia. It was recorded in two reservoirs in the western spurs of the Kolyvan Range in the southwest of Altaiskii Krai (loc. 5, 6). 
A. imperator is distributed in Africa, Europe and western Asia [Borisov, Haritonov, 2008; Kalkman, Proess, 2015b]. Earlier in Russia, this species was not known east of the Urals [Haritonov, Eremina, 2010]. The easternmost point of the range was located in East Kazakhstan (Dubygalinskoe Lake, 50 $10^{\prime} \mathrm{N}, 81^{\circ} 30^{\prime} \mathrm{E}$ ) [Chaplina et al., 2007]. In Northeastern Kazakhstan, this species is known somewhat northerly of the here reported Siberian finds (Baykonys village, 52 ${ }^{\circ} 56^{\prime} 38^{\prime \prime} \mathrm{N}$, 76²4'05" E) [Borisov, Kosterin, 2014].

Anax parthenope. Dragonflies of this species were quite common in reservoirs (loc. 5, 6), one copulating pair was observed on the Ust'yanka River (loc. 7).

A. parthenope is distributed in Europe, North Africa, and western Asia [Kalkman, Proess, 2015a]. It is common in the Southern Urals [Haritonov, Eremina, 2010]. In the south of Western Siberia, this species is found locally, eastward to Krasnoyarsk and Tuva [Kosterin, Zaika, 2010; Borisov, 2012].

Orthetrum albistylum. This species turned out to be quite common in three localities in the south-west of the Altaiskii Krai, the most northern of which is the main channel in the Rubtsovskiy district $\left(51^{\circ} 17^{\prime} 35^{\prime \prime} \mathrm{N}\right)$ (loc. 3). The nearest locality of $O$. albistylum lies somewhat to the south - in Ust-Kamenogorsk in Eastern Kazakhstan $\left(\mathrm{ca} .50^{\circ} \mathrm{N}\right)$ [Borisov, 2014; Kosterin, pers. comm.]. Earlier in Siberia at such northern latitudes, $O$. albistylum was known only from the thermal springs of the Baikal region and the Chara depression [Borisov, 2016; Borisov, Borisov, 2017].

In the European part of the range, O. albistylum has spread to the north since the 90 s of the last century [Kalkman, Ambrus, 2015a]. In Russia, this species was recently found in the Prisurskiy Nature Reserve in Chuvashia $\left(55^{\circ} 01^{\prime} 50^{\prime \prime} \mathrm{N}, 47^{\circ} 55^{\prime} 10^{\prime \prime} \mathrm{E}\right)$ [Borisova, Karolinsky, 2018]. Probably, just like in Europe, we should expect the spread of this dragonfly in the northern direction also in Siberia.

Orthetrum brunneum. This species was found in 4 localities in the south-west of the Altaiskii Krai: at a large main canal (loc. 3), at reservoirs (loc. 5, 6) and at the warm Ust'yanka River with a predominantly subsoil type of feeding (loc. 7).

In Siberia, until recently, O. brunneum was known only from an old record in the vicinity of Irkutsk [Hagen, $1856]$. In the summer of 2020 , this species was discovered in the city of Novosibirsk $\left(55^{\circ} 03^{\prime} \mathrm{N}\right)$ [Kosterin, pers. comm.]. Our findings were made almost simultaneously in Altaiskii Krai, the northernmost of which at $51^{\circ} 17^{\prime} 35^{\prime \prime} \mathrm{N}$. The nearest location is in Eastern Kazakhstan (Ust-Kamenogorsk, 50 N) [Chaplina, 2004].

In Europe, O. brunneum has been registered to actively spread northward since the 90 s of the last century, which is associated with climate warming [Kalkman, Ambrus, 2015b]. At present, the northernmost point of the range is known in Latvia (near Lake Klānii, $57^{\circ} 28^{\prime} \mathrm{N}$, $21^{\circ} 48^{\prime}$ E) [Kalninšs, 2007]. In the European part of Russia, this species was recently found in Chuvashia (the village of Emishkeevo, $55^{\circ} 02^{\prime} \mathrm{N}, 47^{\circ} 55^{\prime} \mathrm{E}$ ) [Borisova et

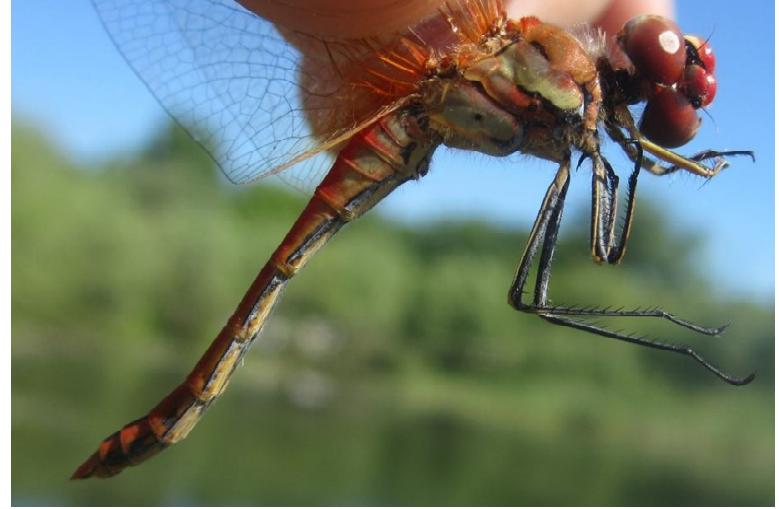

Fig. 2. Sympetrum fonscolombii (loc. 10), male, from Lake Kovalevskoe in Biysk, 12.VI.2019 (photo by A. Noskova).

Рис. 2. Sympetrum fonscolombii (loc. 10), самещ, с оз. Ковалевское в Бийске, 12.VI.2019 (фото А. Носковой).

al., 2019], at approximately the same latitude as in Novosibirsk. Thus, the movement of $O$. brunneum to the north is traced both in the European and Asian parts of the range.

Sympetrum fonscolombii. This report is based on a photograph of a male taken by A. Noskova on Lake Kovalevskoye within the city of Biysk (loc. 10) (Fig. 2).

The range of $S$. fonscolombii covers the Afro-Eurasian region. This species belongs to the obligate migrants, which are characterized by regular seasonal translatitudinal migrations. In spring and early summer, dragonflies migrate to temperate latitudes from southern tropical and subtropical areas of their habitat. During the warm season, the summer temperate generation has time to develop there. In autumn, individuals of this generation make reverse migrations to the south [Borisov, 2011, 2015; Borisov et al., 2020]. In Siberia, the species is at the northern limits of the range and its findings are rare. It was previously recorded in Omsk [Lavrov, 1927], in the vicinity of Lake Chany [Popova, Eremina, 2016], and in the Ubsunur depression in Tuva [Kosterin, Zaika, 2018]. Recently, this species was also found in the Russian Far East in Primorye [Onishko, 2019].

In Biysk, $S$. fonscolombii was photographed on 12 June. Its coloration (Fig. 2) corresponded to a sexually mature male, that means this was an immigrant from the south. In Siberia, due to temperature conditions, the winter development of the larvae of this species with emerging of dragonflies in the first half of summer is excluded [Borisov et al., 2020].

\section{Acknowledgements}

I am gratitude to R.Yu. Dudko and A.A. Legalov (Novosibirsk, ISEA) for organizing the expedition, O.E. Kosterin (Novosibirsk, ICG) for clarifications in the identification of dragonflies, and A. Noskova (Biysk) for the information and photograph provided.

The work was supported by the Federal Fundamental Scientific Research Program for 2021-2025 (0247-2021-0002). 


\section{References}

Belyshev B.F. 1958. [New materials on the fauna of dragonflies in Altai Krai] // Scientific notes of Biysk State Pedagogical Institute. No.3. P.85-111. [In Russian].

Belyshev B.F. 1968. [Contributions to the knowledge of the fauna of dragonflies (Odonata) of Siberia. IV. Geography of the dragonflies of Siberia] // Fragmenta faunistica. Vol.14. No.13. P.407-536. [In Russian]

Belyshev B.F. 1973. [The dragonflies of Siberia]. Nauka: Novosibirsk. Vol.1. Part 1, 2. 620 p. [In Russian].

Borisov A.S., Borisov S.N. 2017. Distribution of Orthetrum albistylum (Selys, 1848) (Odonata, Libellulidae) in thermal springs of the Baikal rift zone, Russia // Evraziatskii Entomologicheskii Zhurnal (Euroasian Entomological Journal). Vol.16. No.4. P.299-303. [In Russian, with English summary].

Borisov S.N. 2011. Migrant dragonflies in Middle Asia. 2. Sympetrum fonscolombii (Selys, 1840) (Odonata, Libellulidae) // Evraziatskii Entomologicheskii Zhurnal (Euroasian Entomological Journal). Vol.10. No.4. P.415421. [In Russian, with English summary].

Borisov S.N. 2012. Migrant dragonflies in Middle Asia. 4. Anax parthenope parthenope (Selys, 1834) (Odonata, Aeshnidae) // Evraziatskii Entomologicheskii Zhurnal (Euroasian Entomological Journal). Vol.11. No.3. P.239-248 [In Russian, with English summary].

Borisov S.N. 2014. Dragonflies (Odonata) of thermal springs in Barguzinskaya depression of Baikalian rift zone, Russia // Evraziatskii Entomologicheskii Zhurnal (Euroasian Entomological Journal). Vol.13. No.2. P.121-132. [In Russian, with English summary].

Borisov S.N. 2015. Migrations of dragonflies (Odonata) in Central Asia: a review. Part 1. Latitudinal migrations // Evraziatskii Entomologicheskii Zhurnal (Euroasian Entomological Journal). Vol.14. No.3. P.241-256. [In Russian, with English summary].

Borisov S.N. 2016. Dragonflies (Odonata) of the Barguzinskaya depression and of the Svyatoi Nos Peninsula (North-Eastern Baikal region, Russia) // Evraziatskii Entomologicheskii Zhurnal (Euroasian Entomological Journal). Vol.15. No.4. P.339-348. [In Russian, with English summary]

Borisov S.N., Haritonov A.Yu. 2007. The Dragonflies (Odonata) of Middle Asia. Part 1. Caloptera, Zygoptera // Evraziatskii Entomologicheskii Zhurnal (Euroasian Entomologica Journal). Vol.6. No.4. P.343-360. [In Russian, with English summary].

Borisov S.N., Haritonov A.Yu. 2008. The Dragonflies (Odonata) of Middle Asia. Part 2 (Anisoptera) // Evraziatskii Entomologicheskii Zhurnal (Euroasian Entomological Journal). Vol.7. No.2. P.97-123 [In Russian, with English summary].

Borisov S.N., Iakovlev I.K., Borisov A.S., Zuev A.G., Tiunov A.V. 2020. Isotope evidence for latitudinal migrations of the dragonfly Sympetrum fonscolombii (Odonata: Libellulidae) in Middle Asia // Ecological Entomology. Vol.45. P.14451456. DOI: 10.1111/een.12930.

Borisov S.N., Kosterin O.E. 2014. Dragonflies and Damselflies (Odonata) of north-eastern Kazakhstan // Evraziatski Entomologicheskii Zhurnal (Euroasian Entomological Journal). Vol.13. No.4. P.339-345.

Borisova N.V., Karolinsky E.A. 2018. [First record of the WhiteTailed Skimmer (Orthetrum albistylum (Selys, 1848) (Odonata: Libellulidae) from the Chuvash Republic] // Natural science research in Chuvashia: materials of reports of the regional scientific and practical conference (Cheboksary, November 27, 2018). No.5. Cheboksary: New time. P.5556. [In Russian, with english name].

Borisova N.V., Karolinsky E.A., Egorov L.V. 2019. [Right Brown (Orthetrum brunneum (Fonscolombe, 1837)) (Odonata: Libellulidae) - a new species of the fauna of Chuvashia] // Scientific works of the state nature reserve «Prisurskiy». Vol.34. P.82-85. [In Russian].
Boudot J.-P., Šalamun A. 2015. Ischnura pumilio (Charpentier, 1825) // Boudot J.-P., Kalkman V.J. (Eds): Atlas of the European Dragonflies and Damselflies. Netherlands: KNNNV Publishing. P.134-136.

Chaplina I.A. 2004. [Fauna and ecology of dragonflies in Kazakhstan]. Diss... kand. biol. nauk. Novosibirsk. 257 p.

Chaplina, I.A., Dumont H.J., Haritonov A.Yu., Popova O.N. 2007. A review of the Odonata of Kazakhstan // Odonatologica. Vol.36. P.349-364.

Dumont H.J. 2003. Odonata from the Republic of Mongolia and from the Autonomous Region of Inner Mongolia // International Journal of Odonatology. Vol.6. No.2. P.127146.

Hagen H. 1856. Odonates de la Russie // Etudes Entomologiques, redigees par Victor de Motschulsky. Helsingfors. P. 52-59.

Haritonov A.Yu., Borisov S.N., Popova O.N. 2007. [Odonatological researches in Russia] // Evraziatskii Entomologicheskii Zhurnal (Euroasian Entomological Journal). Vol.6. No.2. P.143-156. [In Russian, with English summary].

Haritonov A.Yu., Eremina E.E. 2010. [The dragonflies (Odonata) of South Ural: the value of regional faunistic research] // Evraziatskii Entomologicheskii Zhurnal (Euroasian Entomological Journal). Vol.9. No.2. P.263-273. [In Russian, with English summary].

Kalkman V.J., Ambrus A. 2015a. Orthetrum albistylum (Selys, 1848) // Boudot J.-P., Kalkman V.J. (Eds): Atlas of the European Dragonflies and Damselflies. Netherlands: KNNNV Publishing. P. 272-274.

Kalkman V.J., Ambrus A. 2015b. Orthetrum brunneum (Fonscolombe, 1837) // Boudot J.-P., Kalkman V.J. (Eds): Atlas of the European Dragonflies and Damselflies. Netherlands: KNNNV Publishing. P. 274-276.

Kalkman V.J., Proess R. 2015a. Anax parthenope (Selys, 1839). // Boudot J.-P., Kalkman V.J. (Eds): Atlas of the European Dragonflies and Damselflies. Netherlands: KNNNV Publishing. P.177-179.

Kalkman V.J., Proess R. 2015b. Anax imperator Leach, 1815 // Boudot J.-P., Kalkman V.J. (Eds): Atlas of the European Dragonflies and Damselflies. Netherlands: KNNNV Publishing. P. 173-175.

Kalkman V.J., Willigalla C. 2015. Sympecma fusca (Vander Linden, 1820) // Boudot J.-P., Kalkman V.J. (Eds): Atlas of the European Dragonflies and Damselflies. Netherlands: KNNNV Publishing. P.64-65.

Kalninš M. 2007. Brown Orthetrum Orthetrum brunneum (Fonscolombe, 1837) (Odonata, Libellulidae) — a new dragonfly species in Latvia // Acta Biologica Universitatis Daugavpiliensis. Vol.7. No.2. P.109-111.

Kosterin O.E. 1987. [Discovery of East Asiatic dragonfly (Odonata, Libellulidae) at the Manzherock Lake (Altay)]. In: Insects, Mites, and Helmints. New and little-known species of the fauna of Siberia. Novosibirsk: Nauka. P.57-63. [In Russian, with English summary].

Kosterin O.E. 2004. Odonata of the Daurskii State Nature Reserve area, Transbaikalia, Russia // Odonatologica. Vol.33. P. 41-71.

Kosterin O.E. 2013. [New data on dragonflies (Odonata) of Akademgorodok and its surroundings] // Dynamics of the ecosystems of the Novosibirsk Academgorodok. Novosibirsk: SB RAS, P.204-209.

Kosterin O.E., Ahmadi A. 2018. Odonata observed in Central Zagros, Iran, in late May 2017 // International Dragonfly Fund-Report. No.117. P.1-65.

Kosterin O.E., Zaika V.V. 2010. Odonata of Tuva, Russia // International Journal of Odonatology. Vol.13. P.277-328.

Kosterin O.E., Zaika V.V. 2018. Update to the knowledge of Odonata of Tuva and southern Krasnoyarskiy Kray, Siberia, Russia // International Dragonfly Fund-Report. No.113. P. $1-28$.

Lavrov S.D. 1927. Materials to studying of entomofauna of vicinities of Omsk // Trudy Sibirskogo Instituta Sel'skogo Khozayjstva i Lesovodstva. Vol.8. No.3. P.51-100. [In Russian] 
Malikova E.I., Kosterin O.E. 2019. Check-list of Odonata of the Russian Federation // Odonatologica. Vol.48. P.49-78. DOI: $10.5281 /$ zenodo. 2677689

Onishko V.V. 2019. New records of dragonflies (Odonata) for Russia, with notes on the distribution and habitats of rare species // Evrasiatskii entomologicheskii zhurnal (Euroasian Entomological Journal). Vol.18. No.3. P.222-230. [In Russian, with English summary].

Popova O.N., Eremina E.E. 2016. Sympetrum fonscolombi (Selys, 1840) (Odonata, Libellulidae) in northernmost areal localities in Chelyabinskaya and Novosibirskaya Oblast's of Russia // Evraziatskii entomologicheskii zhurnal (Euroasian Entomological Journal). Vol.15. P.45-59 [In Russian, with English summary].
Schneider T., Ikemeyer D., Müller O., Dumont H.J. 2018. Checklist of the dragonflies (Odonata) of Iran with new records and notes on distribution and taxonomy // Zootaxa. 4394(1). P.1-40.

Selys-Longchamps Ed., McLachlan R. 1872. Materiaux pour une faune Nevropterologique de L'Asie septentrionale // Annales de la Societe entomologique de Belgique. Bruxelles. Bd.15. S.25-45.

Schröter A., Seehausen M., Kunz B., Günther A., Schneider T., Jödicke R. 2015. Update of the Odonata fauna of Georgia, southern Caucasus ecoregion // Odonatologica. Vol.44. P.279-342. Seehausen M., Fiebig J. 2016. A collection of Odonata from North Korea, with first record of Ischnura elegans (Odonata: Coenagrionidae) // Notulae odonatologicae. Vol.8. No.7. P. 203-245. 